\title{
PERSATUAN DAN KESATUAN BANGSA INDONESIA
}

DIMAS TAMAELA ,/2111B0013

IIK STRADA INDONESIA

DIMASTAMAELA94@GMAIL.COM

\section{A.LATAR BELAKANG}

Bangsa Indonesia dikenal sebagai bangsa majemuk, ditandai dengan banyaknya etnis, suku, agama, budaya, kebiasaan, di dalamnya. Di sisi lain, masyarakat Indonesia dikenal sebagai masyarakat multikultural, masyarakat yang anggotanya memiliki latar belakang budaya (cultural background) beragam. Kemajemukan dan multikulturalitas mengisyaratkan adanya perbedaan. Bila dikelola secara benar, kemajemukan dan multikulturalitas menghasilkan energi hebat. Sebaliknya, bila tidak dikelola secara benar, kemajemukan dan multikulturalitas bisa menimbulkan bencana dahsyat.

Nation and character building sebagai cita-cita membentuk kebudayaan nasional sebagai wahana pemersatu bangsa cenderung belum terwujud. Malah akhir-akhir ini semangat yang menjurus pada kesukubangsaan semakin bertambah besar sepertinya semangat mengutamakan paham suku-bangsa lebih beradab dan maju ketimbang sukubangsa yang lainnya cenderung tumbuh. Padahal semangat kesukubangsaan yang lebih mengutamakan kebesaran suku-bangsanya di tengah-tengah negara yang multikultur ini tentunya tidak sejalan dengan paham kebangsaan yang dikembangkan sejak negara ini berdiri.

\section{B.MAKNA DAN PENTINGNYA PERSATUAN DAN KESATUAN BANGSA}

Kesatuan bangsa Indonesia yang kita rasakan saat ini, itu terjadi dalam proses yang dinamis dan berlangsung lama, karena persatuan dan kesatuan bangsa terbentuk dari proses yang tumbuh dari unsur-unsur sosial budaya masyarakat Indonesia sendiri, yang ditempa dalam jangkauan waktu yang lama sekali.

Unsur-unsur sosial budaya itu antara lain seperti sifat kekeluargaan dan jiwa gotong-royong. Kedua unsur itu merupakan sifat-sifat pokok bangsa Indonesia yang dituntun oleh asas kemanusiaan dan kebudayaan. Karena masuknya kebudayaan dari luar, maka terjadi proses akulturasi (percampuran kebudayaan). Kebudayaan dari luar itu adalah kebudayaan Hindu, Islam, Kristen dan unsur-unsur kebudayaan lain yang beraneka ragam. Semua unsur-unsur 
kebudayaan dari luar yang masuk diseleksi oleh bangsa Indonesia. Jadi makna dan pentingnya persatuan dan kesatuan bangsa dapat mewujudkan sifat kekeluargaan, jiwa gotong-royong, musyawarah dan lain sebagainya.

Tahap-tahap pembinaan persatuan bangsa Indonesia itu yang paling menonjol ialah sebagai berikut:

1. Perasaan senasib

2. Kebangkitan Nasional

3. Sumpah Pemuda

4. Proklamasi Kemerdekaan

\section{C.PRINSIP-PRINSIP PERSATUAN DAN KESATUAN}

Hal-hal yang berhubungan dengan arti dan makna persatuan Indonesia apabila dikaji lebih jauh, terdapat beberapa prinsip yang juga harus kita hayati serta kita pahami lalu kita amalkan.

\section{D.PENGAMALAN NILAI NILAI PERSATUAN KESATUAN}

Pengamalan Nilai-nilai Persatuan dan Kesatuan antara lain Mempertahankan Persatuan dan Kesatuan Wilayah Indonesia. Pepatah mengatakan "bersatu kita teguh, bercerai kita runtuh". Oleh karena itu yang perlu kita tegakkan dan lakukan adalah:

1. meningkatkan semangat kekeluargaan, gotong-royong dan musyawarah; meningkatkan kualitas hidup bangsa Indonesia dalam berbagai aspek kehidupan

2. pembangunan yang merata serta berkeadilan sosial bagi seluruh rakyat Indonesia;

3. memberikan otonomi daerah;

4. memperkuat sendi-sendi hukum nasional serta adanya kepastian hokum

5. perlindungan, jaminan serta menjunjung tinggi hak asasi manusia;

6. memperkuat sistem pertahanan dan keamanan sehingga masyarakat merasa terlindungi;

7. Meningkatkan semangat Bhinneka Tunggal Ika;

8. Mengembangkan semangat kekeluargaan.Yang perlu kita lakukan setiap hari usahakan atau "budayakan saling bertegur sapa";

9. Menghindari penonjolan sara/perbedaan. Karena bangsa Indonesia terdiri dari berbagai macam suku, bahasa, agama serta adat-istiadat kebiasaan yang berbeda-beda, maka kita tidak boleh melakukan perbuatan yang dapat menimbulkan perpecahan.

Oleh karena itu yang harus kita hindari antara lain: 

a. Egoisme
b. Ekstrimisme
c. Sukuisme
d. Profinsialisme
e. acuh tak acuh tidak peduli terhadap lingkungan

\section{E. Faktor pendorong persatuan dan kesatuan}

1. Rasa Nasionalisme

2. Rasa Toleransi yang tinggi

3. Kesadaran dalam hidup bermasyarakat, sehingga timbul keinginan dari dalam hati untuk selalu membantu sesama, mengikuti kegiatan sosial, dan lain-lain.

4. Rela berkorban untuk kepentingan bangsa dan negara seperti jasa pahlwan yang telah melawan para penjajah.

5. Adanya rasa senasib dan sepenanggungan yang diakibatkan oleh penderitaan semasa penjajahan..

\section{F. Faktor penghambat persatuan dan kesatuan}

1. rasa egois tinggi terhadap kebenaran Ras, suku, agama, dan bu

1. daya sendiri

2. Rasa iri dengki juga menadi salah satu faktor penghambat persatuan dan kesatuan Indonesia

3. Kurang adanya rasa toleransi beragama, berbudaya, ataupun berpendapat

4. Kurangnya penghargaan terhadap kemajemukan yang memiliki sifat heterogen.

5. Kurangnya kesadaran di dalam diri masing-masing rakyat Indonesia terhadap segala ancaman dan gangguan yang mucul dari luar

\section{E.Penutup}

Telah kita ketahui bersama bahwa bangsa Indonesia adalah bangsa yang memiliki banyak ragam budaya yang berbeda-beda dari setiap suku daerah yang berbeda pula. Perbedaan itu sendiri justru memberikan 
kontribusi yang cukup besar pada citra bangsa Indonesia. Kebudayaan dari tiap-tiap suku daerah inilah yang menjadi penyokong dari terciptanya budaya nasional Indonesia.

Identitas budaya nasional kita saat ini memang belum jelas selain hanya bahasa Indonesia sebagai bahasa nasional dan Pancasila sebagai filosofi atau pandangan hidup bangsa. Selain itu, perbedaan juga akan menyulut terjadinya sebuah konflik jika para pelakunya tidak dapat mengendalikan emosi mereka masing-masing. Lingkungan dan masyarakat sangatlah menentukan bagaimana sebuah kebudayaan itu tumbuh dan berkembang di dalam masyarakat itu sendiri. 